\title{
Effects of replacement of binder content on bond strength of mortars
}

\section{Efeito do teor de substituição do ligante na aderência de argamassas}

E. B. C. COSTA a

elianecosta@utfpr.edu.br

B. L. DAMINELI

bruno.damineli@Ime.pcc.usp.br

V. B. FREITAS ${ }^{\circ}$ veronicafreitasb@gmail.com

V. M. JOHN

vmjohn@Ime.pcc.usp.br

\begin{abstract}
The reduction of binder content in cementitious systems is an effective way to mitigate environmental impacts without increasing costs. The main purpose of this study is to evaluate the effect of content binder on bond strength of mortar-brick interface. For thus, it was studied mortars produced with two limestone fines with different particle size distribution. The limestone fines were added at rates of $0 \%$ to $60 \%$ at increments of $15 \%$ as partial volume replacement of binder. Mortars were prepared in proportion of 1:3 (binder + limestone: sand) in volume. The water content was kept constant and equal to $18 \%$ in relation to total weight of solids. The mechanical property of mortars was evaluated by tensile strength and the performance of interface by bond strength tests at 14 days. Results indicate that is possible make mortars with $45 \%$ less than binder without reducing bond strength. Thus, the use of appropriate particles of limestone can produce more environmentally friendly concrete and rendering mortars by reducing its binder factor without affecting its performance.
\end{abstract}

Keywords: limestone; binder content; bond strength; mortars.

\section{Resumo}

A redução do teor de ligante em produtos cimentícios é uma forma eficiente de mitigar os impactos ambientais sem aumentar os custos. $\mathrm{O}$ objetivo deste trabalho é estudar efeito do teor de ligante na resistência de aderência da interface argamassa-substrato. Para tanto, foram empregadas argamassas produzidas em laboratório com dois finos calcários com distribuições granulométricas diferentes. Os finos calcários foram adicionados em teores de $0 \%$ a $60 \%$ em taxas de incrementos de $15 \%$ em substituição ao volume de ligante. As argamassas foram preparadas na proporção de 1:3 (ligante+calcário: areia) em volume. O teor de água foi mantido constante e igual a $18 \%$ em relação à massa total de sólidos. O desempenho mecânico das argamassas foi avaliado pela resistência à tração por compressão diametral e o da interface pela resistência de aderência à tração, ambos aos 14 dias. Os resultados indicaram que é possível produzir argamassas com substituição de $30 \%$ do ligante por fino calcário sem reduzir a resistência de aderência. Assim, o uso de finos calcários com granulometria adequada pode contribuir para a produção de concretos e argamassas com menor teor de ligante aumentando a ecoeficiência dos sistemas sem comprometer o desempenho.

Palavras-chave: calcário; teor de ligante; resistência de aderência; argamassas.

\footnotetext{
Departamento Acadêmico de Construção Civil, Universidade Tecnológica Federal do Paraná, Curitiba, Brasil;

Escola Politécnica, Departamento de Engenharia de Construção Civil, Universidade de São Paulo, Paulo, Brasil;

Faculdade de Tecnologia de São Paulo, Departamento de Construção Civil, São Paulo, Brasil.
} 


\section{Introduction}

The adhesion between surfaces it is an important property in many practical applications in civil engineering, including injection grouts, masonry, rendering and adhesive mortars, and aggregate-mortar interfaces in concretes. In cementitious systems, the interfacial transition zone (ITZ) between the substrate (either an external substrate such as a brick or an internal one such as an aggregate) and the cement paste is considered the weakest zone in cementitious composites because it is more porous than the bulk paste. The porosity of this region can be improved by the reduction of the water content, by the compaction energy, by the addition of fine particles and by the degree of hydration of the binder [2,3]. The roughness of the surface, the viscosity of the cementitious matrix, also determine the contact area between the substrate and the matrix.

There have been a number of studies demonstrating it is possible to reduce the porosity of the ITZ and improve the strength of concrete and mortars by adding or replacing clinker with supplementary materials such as silica fume, blast-furnace slag, fly ash and limestone. Particles finer than those of conventional cements, reactive or not, can reduce the porosity by the filler effect act as nucleation sites and by the hydration reactions $[3,4]$. Pozzolanic materials, for instance, react with calcium hydroxide and form hydrated silicate calcium, thus densifying the interface [5].

However, owing to the limited availability of more reactive supplementary cementitious materials, such as fly ash and blast furnace slag [6], much higher values of ultrafine may become standard for improve cementitious systems. Moreover, the replacement of binder by fines particles will contribute to reducing $\mathrm{CO}_{2}$ emissions generated by cement production. Thus, limestone fines become an attractive solution.

The primary effect of using limestone as a filler in cement-based materials is that it reduces the porosity of the cement by physical effect. Additionally, it can also act as a reactive participant in the hydration process and/or accelerate the binder reaction, owing to the nucleation effect. At normal temperatures $\left(\sim 25^{\circ} \mathrm{C}\right)$, limestone can react with the sulfoaluminates, altering the mineralogy of hydrated cement pastes and generating monocarboaluminate, thereby increasing the volume of solids up to $0.5 \%[7,8]$ showing little impact in the compressive strength. The amount of limestone filler that can react is limited by sulphate and alumina contents of the cement and even when it is added in amounts as small as 5\%, thermodynamic simulations show that not all of it is consumed 7]. For higher amounts, the potential for subsequente reactions is reduced, with the added limestone acting only as a filler.

Replacing $15 \%$ to $20 \%$ of the binder with limestone filler does not have a significant impact on the compressive strength [10-12], even if one does not control the size distribution and surface area of the resulting particles. Camiletti et al. [13] found that the addition of micro-and nanoparticles of $\mathrm{CaCO}_{3}$ in concrete creates a denser microstructure and increases the effective water/solid ratio, because the $\mathrm{CaCO}_{3}$ particles cover and fill the voids between the hydration products as well as the space around the larger particles. There is no evidence that the replacement of the binder with limestone in such high amounts has an effect on the ITZ, including on the bond strength between the cement paste and substrates such as aggregates and bricks.

Thus, the aim of this study was to investigate the effects of replacing the binder with limestone fines with different particle size distributions on the interfacial bond strength of mortar-brick composites.

\section{Materials and methods}

The effects of the limestone content on the bond strength were evaluated using a reference mortar (sand and cement) and mortars prepared by partially replacing the binder with limestone fines in contents of $15 \% ; 30 \% ; 45 \%$ and $60 \%$ of the total volume of cement applied on the surfaces of the clay bricks treated with a water repellent. The mortars were prepared in proportion of 1:3 in volume, this is, 25 parts of fines (binder and limestone) and 75 parts a sandquartz aggregate by volume. The water content was kept constant at $18 \%$ of the total weight or mass of the solids. It was used two types of limestone fines with different particle size distribution, one thinner than and other with similar cement particle size. The mechanical performance of mortars was evaluated by the tensile strength and of the interface by bond strength tests both after 14 days.

\subsection{Substrate used}

Mortars were applied on extruded fire ceramic clay-type bricks, selecta type, dimensions $9 \times 19 \times 39 \mathrm{~cm}$. The pore size distributions of the bricks were determined by mercury intrusion porosimetry of samples, equipment Micromeritics - Autopore III 9420, adopting as test conditions: surface tension of mercury equal to $0.485 \mathrm{~N} / \mathrm{m}$; density of 15.53 $\mathrm{g} / \mathrm{cm}^{3}$ and contact angle mercury/solid $130^{\circ}$. The samples was taken from the surface up to a depth of $2 \mathrm{~mm}$. The total pore volume was equal to $36 \%$ and the pore size distribution is shown in Figure 1.

\subsection{Preparation of substrates}

In order to avoid the effects of capillary suction by the substrate, which could affect the on fluid transporting of mortar, a waterrepelling agent based on octyltriethoxysilane (Dow Corning-IE 6683) was applied on the surfaces of the bricks used as substrates. The water repelente was diluted in a weight ratio of 1:9

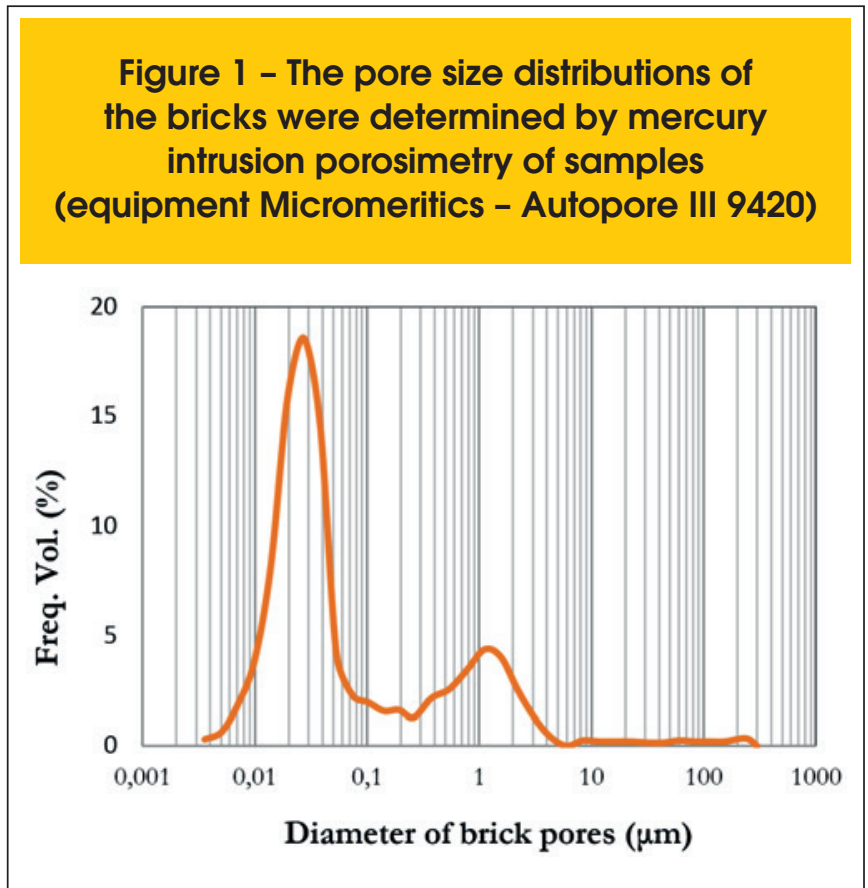




\section{Figure 2 - Capillary action-based water absorption by untreated clay bricks and those treated superficially with silane}

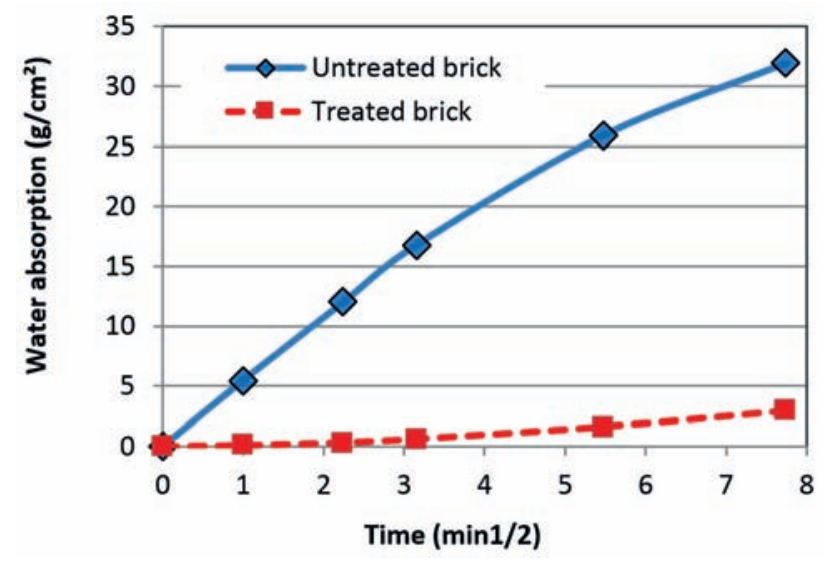

(water repelente:water) and applied on the brick surfaces with a brush in three consecutive layers. Then, the bricks were dried in air for $24 \mathrm{~h}$ before applying mortar.

The effectiveness of this treatment was measured throught capillary water absorption and on the basis of the contact angles of the treated and untreated bricks with silane. In order to facilitate the execution of the tests, the bricks were cu tinto dimensions of 10 $x 10 \mathrm{~cm}$; cutting was performed dry with diamond saw. After the

\begin{tabular}{|c|c|c|c|}
\hline \multicolumn{4}{|c|}{$\begin{array}{c}\text { Table } 1 \text { - Contact angles between water } \\
\text { drops and untreated bricks and bricks } \\
\text { treated superficially with silane } 60 \mathrm{~s} \text { after the } \\
\text { placement of the drop }\end{array}$} \\
\hline $\begin{array}{l}\text { Silane } \\
\text { treatment }\end{array}$ & $\mathbf{n}$ & Average & CV $(\%)$ \\
\hline No - CER & 30 & $35.4^{\circ}$ & 20 \\
\hline Yes - CER-H & 30 & $100.1^{\circ}$ & 10 \\
\hline \multicolumn{4}{|c|}{$\mathrm{n}$ - number of specimens evaluated; $\mathrm{CV}$ - coefficient of variation. } \\
\hline
\end{tabular}

cutting, the lateral surfaces of the specimens were sealed with silicone rubber in order to ensure one-dimensional water transport. The amounts of water absorbed by capillary action by the bricks were measured using the method described by Taha et al. [15]. The specimens were immersed in water at a depth of $5 \mathrm{~mm}$ for 1 , $5,10,30$, and $60 \mathrm{~min}$. The amounts of water absorbed by capillary suction were determined by weighing the specimens and calculating the differences in their weights. For each situation were evaluated six specimens whose results are shown in Figure 2.

The contact angles of the bricks were measured using the sessile drop method; a contact-angle goniometer (DSA10, Krüss) was employed for the purpose. The measurements were made $60 \mathrm{~s}$ after the placement of the drop. The values were recorded at $25^{\circ} \mathrm{C}$ using deionised water; all the droplets were $8 \mu \mathrm{L}$ in volume. The obtained results are shown in Table 1 and they are the averages of thirty measurements performed for each specimen type. The results of the absorbed-water and contact-angle measure-

Table 2 - Chemical compositions of the cement and limestone fines used

\begin{tabular}{|c|c|c|c|}
\hline \multirow{2}{*}{ Oxides (\%) } & \multirow{2}{*}{ Cement } & \multicolumn{2}{|c|}{ Limestone fines } \\
\hline & & LF1 & LF2 \\
\hline $\mathrm{CaO}$ & 61.6 & 47.7 & 47.5 \\
\hline $\mathrm{SiO}_{2}$ & 17.6 & 1.94 & 4.16 \\
\hline $\mathrm{Al}_{2} \mathrm{O}_{3}$ & 4.98 & 0.59 & 0.40 \\
\hline $\mathrm{Fe}_{2} \mathrm{O}_{3}$ & 2.62 & $<0.10$ & $<0.10$ \\
\hline $\mathrm{MgO}$ & 1.99 & 5.99 & 5.64 \\
\hline $\mathrm{Na}_{2} \mathrm{O}$ & 0.33 & 0.00 & 0.00 \\
\hline $\mathrm{K}_{2} \mathrm{O}$ & 1.00 & $<0.10$ & $<0.10$ \\
\hline $\mathrm{SO}_{3}$ & 3.69 & $<0.10$ & $<0.10$ \\
\hline Loss on ignition - NBR - NM 18/04 & 4.87 & 43.1 & 41.2 \\
\hline Free calcium oxide - NBR - NM 13/04 & 2.29 & - & - \\
\hline Insoluble residue - NBR - NM 15/04 & 0.48 & 2.97 & 6.82 \\
\hline $\mathrm{CO}_{2}$ (carbono dioxide) - NBR - NM 20/04 & 2.67 & 41.6 & 39.4 \\
\hline Equivalent álcalis in mass \% of $\mathrm{Na}_{2} \mathrm{O}^{\prime}$ & 0.99 & - & - \\
\hline
\end{tabular}




\section{Figure 3 - Particle size distributions of the raw materials used, as measured by laser diffraction analysis (binder and fines) and dry sieving (sand)}

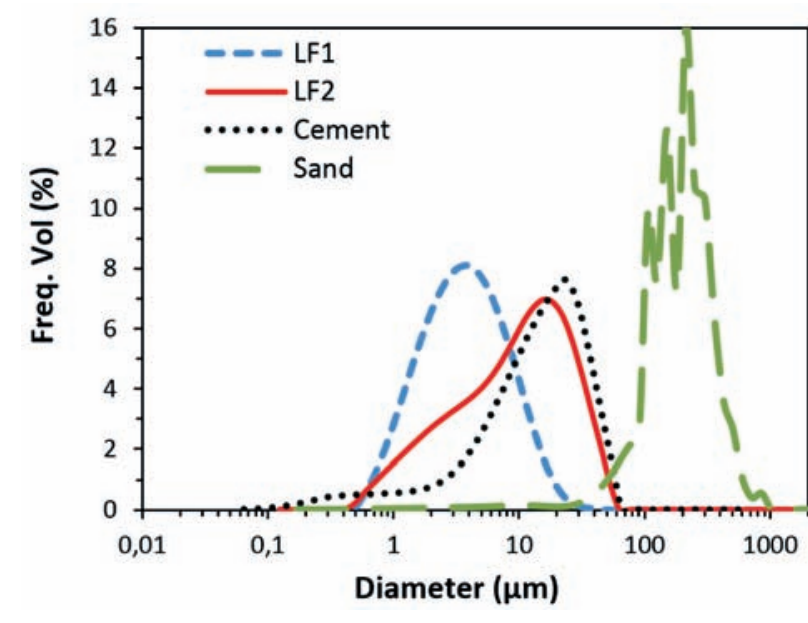

ments indicated that the silane-based water repellent agent had a significant effect on the capillary action-based water absorption by the clay bricks. The amount of water absorbed by the silanetreated bricks was $91 \%$ lower than that in the case of the untreated bricks after immersion in water for $60 \mathrm{~min}$. Thus, the treatment was effective in significantly decreasing capillary absorption.

\subsection{Particulate materials: cement; limestone fines and sand}

The mortars were prepared using Portland cement type CPV ARI
(Cauê), two types of limestone fillers (LF1 and LF2), commercially called as Procarb 1 and Procarb 5 (Provale) having different particle size distributions, and crushed granite sand.

Table 2 shows the chemical compositions of the cement and limestone fines, were determined by $\mathrm{X}$-ray fluorescence $(\mathrm{XRF})^{1}$ analysis and complementary chemical analysis. The calcium carbonate content was determined from the relationship between the molecular weight of calcium carbonate and carbon dioxide (Equation 1), which was determined by chemical analysis. The results of the chemical analysis revealed that LF1 contained fewer impurities $\left(\mathrm{SiO}_{2}+\mathrm{Al}_{2} \mathrm{O}_{3}+\mathrm{Fe}_{2} \mathrm{O}_{3}\right)$ than did LF2 and that both contained calcium and dolomite carbonates.

$$
\% \mathrm{CaCO}_{3}=\frac{M_{\mathrm{CaCO}_{3}}}{M_{\mathrm{CO}_{2}}} \cdot \mathrm{CO}_{2}
$$

Where

$M_{\mathrm{CaCO}_{3}}=100$ e $M_{\mathrm{CO}_{3}}$. $=44$

The particle size distributions of the cement and the limestone fines were measured through laser diffraction analysis (MSS Mastersizer, Malvern) with accessory Hydro 2000 A for analysis in wet. The powders were suspended in deionised water and dispersed for 1 min using ultrasonic waves with rotation speed of $1800 \mathrm{rpm}$ until to obscuration of $10 \%$. The measurements were performed in sets of four consecutive 1-min runs per sample. The particle size distribution of the sand was determined by direct sieving and it was dried previously at $105^{\circ} \mathrm{C}$. The sand used showed $34.77 \%$ of pulverulent materials (particles less than $75 \mu \mathrm{m}$ ).

Figure 3 shows the particle size distributions of the raw materials, while their physical properties are listed in Table 3.

The results show that both the limestone fines had particles finer than those of the binder. It can be seen in Fig. 3 that the particles of the cement and LF2 had the same maximum size (approximately $60 \mu \mathrm{m}$ ),

Table 3 - Physical properties of the Cement, limestone fines, and sand used

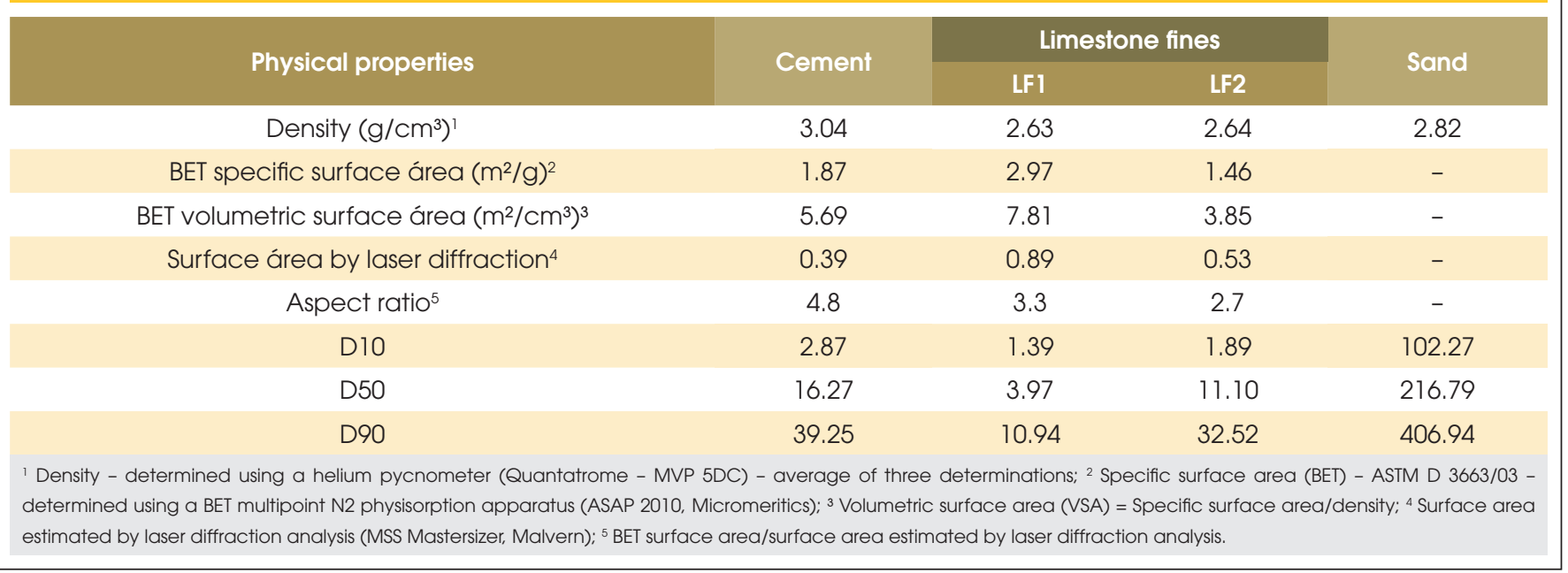




\section{Table 4 - Mix proportion of mortars studied, a traditional cement mortar with $0 \%$ of limestone fines and the others mortars with $15 \% ; 30 \% ; 45 \%$; and $60 \%$ of replacement of binder by both limestone fines (LF1 and LF2) analysed individually}

\begin{tabular}{ccccc}
$\begin{array}{c}\text { Limestone fine content } \\
\text { on mortar (\%) }\end{array}$ & $\begin{array}{c}\text { Mix proportion } \\
\text { in (\% vol) } \\
\text { (cement: limestone } \\
\text { fine: sand) }\end{array}$ & $\begin{array}{c}\text { Mix proportion } \\
\text { (\% mass) } \\
\text { (cement: limestone } \\
\text { fine: sand) }\end{array}$ & w/c ratio & $\begin{array}{c}\text { Cement } \\
\text { consumption } \\
\left(\mathrm{kg} / \mathrm{m}^{3}\right)\end{array}$ \\
\hline 0 & $1: 0: 3.0$ & $1: 0: 2.8$ & 0.68 & 593.0 \\
15 & $1: 0.2: 3.5$ & $1: 0.2: 3.3$ & 0.80 & 504.1 \\
\hline 30 & $1: 0.4: 4.3$ & $1: 0.4: 4.0$ & 0.96 & 415.1 \\
\hline 60 & $1: 0.8: 5.5$ & $1: 0.7: 5.1$ & 1.22 & 326.2 \\
\hline
\end{tabular}

but the filler had a greater number of particles smaller than $15 \mu \mathrm{m}$. The limestone filler LF1 was much finer than the other fines, with its maximum particle size being approximately $20 \mu \mathrm{m}$ and at least $90 \%$ of its particles being smaller than $11 \mu \mathrm{m}$ (D90). The D90 values of LF2 and the cement were $33 \mu \mathrm{m}$ and $39 \mu \mathrm{m}$, respectively.

Table 3 also shows that volumetric surface area (VSA) of LF1 was $37 \%$ higher than that of the cement, while the VSA value of LF2 was $32 \%$ lower than that of the binder. The aspect ratio was determined by dividing the Brunauer-Emmett-Teller (BET) surface area (or the VSA) by the surface area (or the VSA) estimated from the particle size distribution assuming that the particles were perfectly smooth, solid spheres [14]. The results show that, for the three powdered raw materials, the aspect ratio was greater than 1 , indicating that either the particles were not perfectly spherical or that they had rough surfaces. The limestone particles exhibited lower aspect ratios than that of the cement particles, and the aspect ratio of the LF2 particles was lower than that of the LF1 particles, suggesting that the former were more spherical and/or smoother than the latter.

\subsection{Mixture proportions of mortars}

Nine mortars were studied, a traditional cement mortar and eight mortars with the replacement of cement by limestone fines, LF1 and LF2, at levels of $15 \%, 30 \% ; 45 \%$ and $60 \%$ by volume. The water content (deionised water) was constant at $18 \mathrm{wt} \%$ for all the compositions. This corresponds to water cement ratio varying between 0.62 and 1.54, typical of mortars. The proportion of the mortars as well as the consumption of cement and water-cement ratio as shown in Table 4.

\subsection{Mix of mortars}

Mortars were mixing using a Hobart Model A-200 food mixer. The solid componentes was premixed for 1 min inside a plastic bag. Then, it was placed in the vessel and water was added to the dry powder during the first minute. Mortars were mixed for five minutes, one minute at low speed $(140 \mathrm{rpm})$ and the others in a high rotational speed $(500 \mathrm{rpm})$. Each batch was mixed with $2 \mathrm{~kg}$ of dry mortar.

After the mixing, the density of the freshly mixed mortar was measured using the gravimetric method according to Brazilian standard ABNT NBR 13278:2005 to determine the amount of air entrapped with the mortar. The results, shown in Table 5, show that air content

\section{Table 5 - Characterization of mortars studied in fresh and hardened state and the results of bond strength at 14 days for mortars with $0 \% ; 15 \% ; 30 \% ; 45 \%$ e $60 \%$ of the replacement of binder applied on the surfaces of the clay bricks treated with a water repellent}

\begin{tabular}{|c|c|c|c|c|c|c|c|c|}
\hline \multirow{3}{*}{$\begin{array}{l}\text { Limestone } \\
\text { fine content } \\
(\%)\end{array}$} & \multicolumn{4}{|c|}{ Limestone fine $1(\mathrm{LF} 1-\mathrm{D} 90=11 \mu \mathrm{m})$} & \multicolumn{4}{|c|}{ Limestone fine 2 (LF2 - D90 = 33 m) } \\
\hline & \multicolumn{2}{|c|}{ Fresh state } & \multicolumn{2}{|c|}{ Hardened state } & \multicolumn{2}{|c|}{ Fresh state } & \multicolumn{2}{|c|}{ Hardened state } \\
\hline & $\begin{array}{l}\text { Density } \\
\left(\mathrm{g} / \mathrm{cm}^{3}\right)\end{array}$ & $\begin{array}{c}\text { Air content } \\
(\%)\end{array}$ & $\begin{array}{l}\text { Tensile } \\
\text { Strength } \\
\text { (MPa) }\end{array}$ & $\begin{array}{l}\text { Bond } \\
\text { Strength } \\
\text { (MPa) }\end{array}$ & $\begin{array}{l}\text { Density } \\
\left(\mathrm{g} / \mathrm{cm}^{3}\right)\end{array}$ & $\begin{array}{c}\text { Air content } \\
(\%)\end{array}$ & $\begin{array}{l}\text { Tensile } \\
\text { strength } \\
\text { (MPa) }\end{array}$ & $\begin{array}{l}\text { Bond } \\
\text { strength } \\
\text { (MPa) }\end{array}$ \\
\hline 0 & 2.17 & 5.0 & $4.85 \pm 0.22$ & $0.38 \pm 0.15$ & 2.17 & 5.2 & $4.85 \pm 0.22$ & $0.38 \pm 0.15$ \\
\hline 15 & 2.26 & 0.7 & $4.24 \pm 0.51$ & $0.49 \pm 0.15$ & 2.23 & 2.0 & $3.90 \pm 0.57$ & $0.41 \pm 0.12$ \\
\hline 30 & 2.24 & 1.1 & $2.99 \pm 0.49$ & $0.45 \pm 0.16$ & 2.21 & 2.5 & $3.45 \pm 0.61$ & $0.42 \pm 0.19$ \\
\hline 45 & 2.23 & 1.4 & $2.67 \pm 0.40$ & $0.34 \pm 0.09$ & 2.19 & 3.0 & $2.27 \pm 0.24$ & $0.45 \pm 0.14$ \\
\hline 60 & 2.25 & 0.1 & $1.92 \pm 0.16$ & $0.18 \pm 0.06$ & 2.20 & 2.2 & $1.44 \pm 0.14$ & $0.26 \pm 0.09$ \\
\hline
\end{tabular}


of reference mortar was higher for mortar with limestone fines, but in all the cases the amounts were low less than $6 \%$.

\subsection{Tensile strength by brazilian test}

The mortars were evaluated by the splitting tensile strength test (i.e., the Brazilian test). For each mortar type, six samples $50 \mathrm{~mm}$ in diameter and $20 \mathrm{~mm}$ in height were cast with PVC moulding aid. The specimens were moulded in a single layer, and the excess mortar was removed with a spatula. After $24 \mathrm{~h}$, mortars were removed of the mould and the samples were cured in dry chamber at a relative humidity $(\mathrm{RH})$ of approximately $50 \%$ and temperature of

Figure 4 - Specimens used for the bond strength tests. (a) the individual specimens were moulded a few centimetres apart from each other over the ceramic substrate allowing the cutting procedure to be eliminated; it were cast using plastic ring moulds (50 mm in diameter and $20 \mathrm{~mm}$ in heigth) (b)

Specimens after the aplying of mortar and the remotion of plastic ring mould. (c) Side view of specimen after the gluing metallic pull-head plates on the mortar surface (c) the pull-off tensile tests were performed using a traction dynamometer (DTE 5000, Dynatest). Photos: Mario Takeashi (USP)
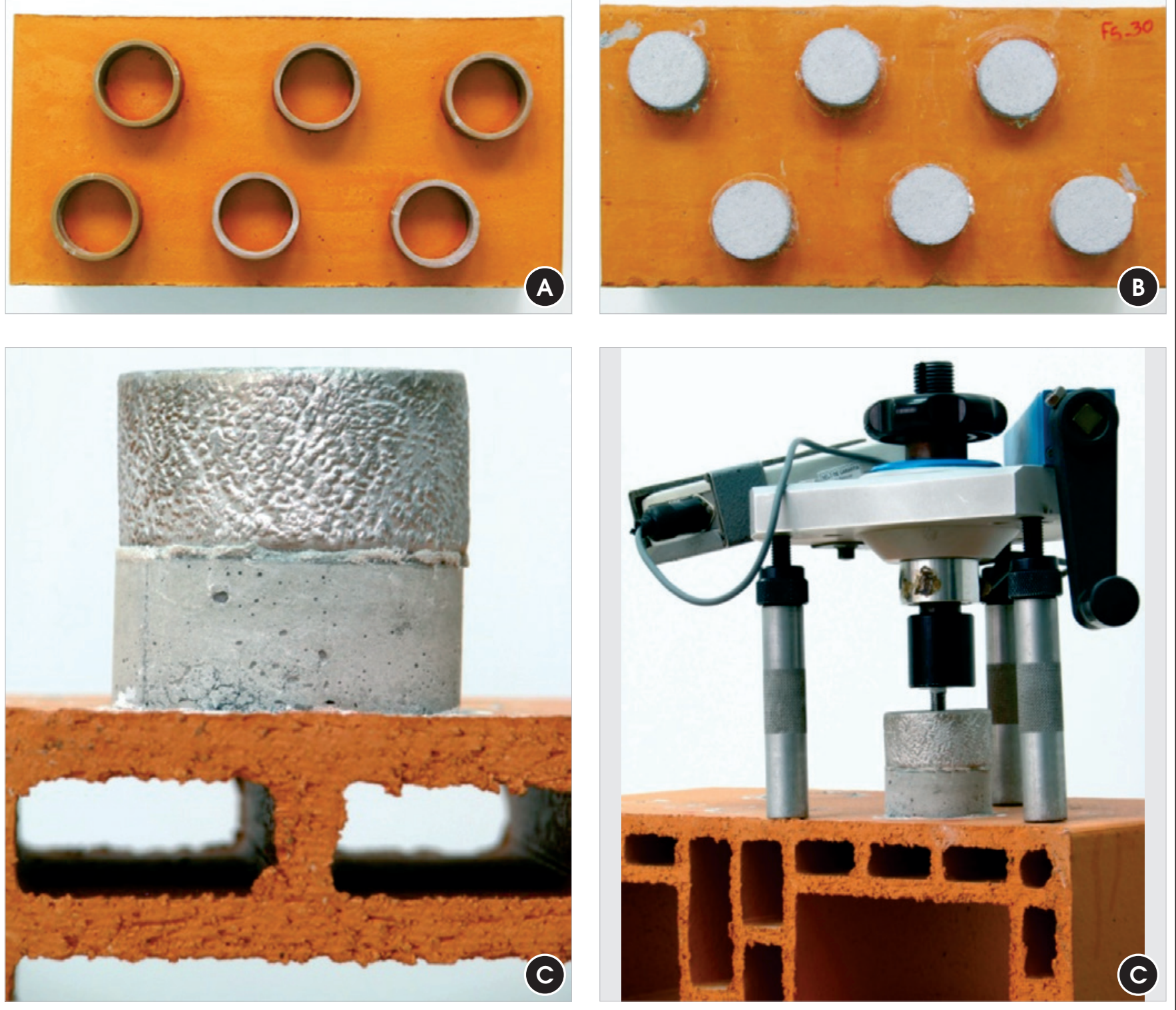
$23^{\circ} \mathrm{C}$ for 14 days. This procedure attempts to simulate the cure the realized in mortar coatings.

The splitting tensile strength test (i.e., the Brazilian test) were performed using a universal testing machine (Model 5569, INSTRON) with a $50 \mathrm{kN}$ load cell; the stress rate was $0.01 \mathrm{MPa} / \mathrm{s}$.

\subsection{Bond strength test}

Figure 4 shows details of the production and preparation of specimens for the bond tensile strength test and the equipment used.

For this test, eighteen specimens were cast over brick surfaces using plastic ring moulds $(50 \mathrm{~mm}$ in diameter and $20 \mathrm{~mm}$ in height). This strategy was adopted to eliminate the need for the cutting procedure to produce a sample for the pull out test. Very fluid mortars were applied to the ceramic bricks in a single layer without compaction.

The excess mortar was removed with a spatula immediately after the molding. The ring moulds were removed from the hardened specimens on the bricks $24 \mathrm{~h}$ after the casting process, and then the systems, that is, the bricks and the mortar specimens, were cured in dry chamber at a temperature of $23^{\circ} \mathrm{C}$ and $\mathrm{RH}$ of $50 \%$ for 13 days. Before the gluing metallic pull-head plates the mortar surface was cleaned to remove loose particles. It was used a polyester adhesive. After $24 \mathrm{~h}$, the pull-off tensile tests were performed using a traction dynamometer (DTE 5000, Dynatest).

\subsection{Binder use efficiency indicator}

The efficiency use of binder was measured by the binder intensity indicator(bi) proposed by Damineli et al. [23] which measures the total amount of binder necessary to deliver one unit of a given performance indicator (Equation 2):

$$
\mathrm{bi}=\frac{\mathrm{b}}{\mathrm{p}}
$$

where $b$ is the total consumption of binder materials in $\mathrm{kg} / \mathrm{m}^{3}$ and $p$ is the performance requirement. In this paper, it was measured the amount of binder required to achieve $1 \mathrm{MPa}$ of tensile strength of mortars and bond strength of system mortar-brick.
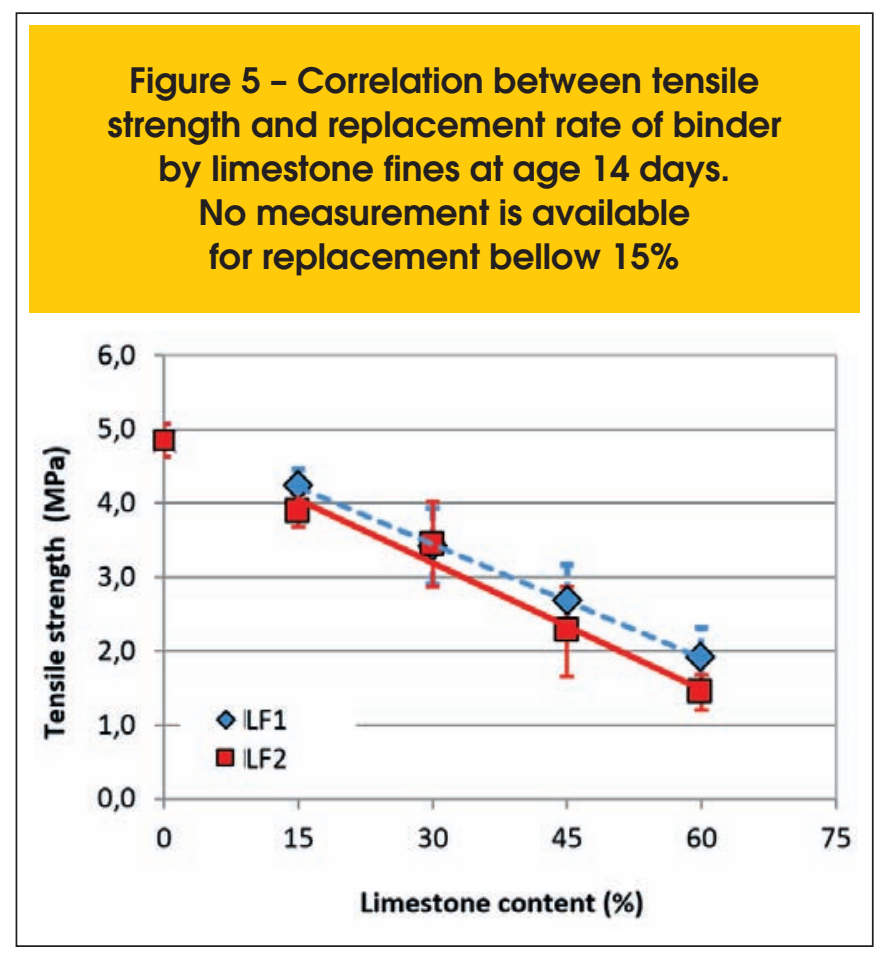

\section{Results and discussion}

\subsection{Mechanical strength of mortars}

The mechanical properties of mortars was evaluated by the splitting tensile strength test. The results show that the mechanical properties of the mortars decrease with an increase in their limestone fines content, as shown in Figure 5. Similar results have been reported in the literature for the compressive strength of a concrete $[9,12]$ to which limestone filler had been added.

There is a trend of reduction in tensile and compressive strength when the water content was kept constant and for high replacement rates owing to the dilution effect, that is, increasing the water/cement ratio (see Table 4). Simultaneously, the increase of water/cement ratio, the addition of limestone fines will also reduce the volume of the hydrated products [17], which for a constant water content implies an increase of porosity with a consequente decrease of strength.

\section{Table 6 - Variance analysis (ANOVA) of the effect of the type and content of limestone fine on bond strength}

\begin{tabular}{|c|c|c|c|c|c|c|}
\hline Source of variation & SS & DF & MS & Fcal & Ftab & Result \\
\hline Limestone fine type (A) & 0.01 & 1 & 0.08 & 0.44 & 3.89 & Non-Significant \\
\hline Limestone fine content (B) & 1.08 & 4 & 0.27 & 14.50 & 2.42 & Significant \\
\hline$A B$ & 0.24 & 4 & 0.06 & 3.16 & 2.42 & Non-Significant \\
\hline Residual & 3.69 & 197 & 0.02 & - & - & - \\
\hline Total & 5.02 & 206 & 0.36 & - & - & - \\
\hline
\end{tabular}


Figure 6 - The relation between the replacement rate of binder by limestone fines and bond strength at 14 days. All mortars presented interface rupture after bond strength test

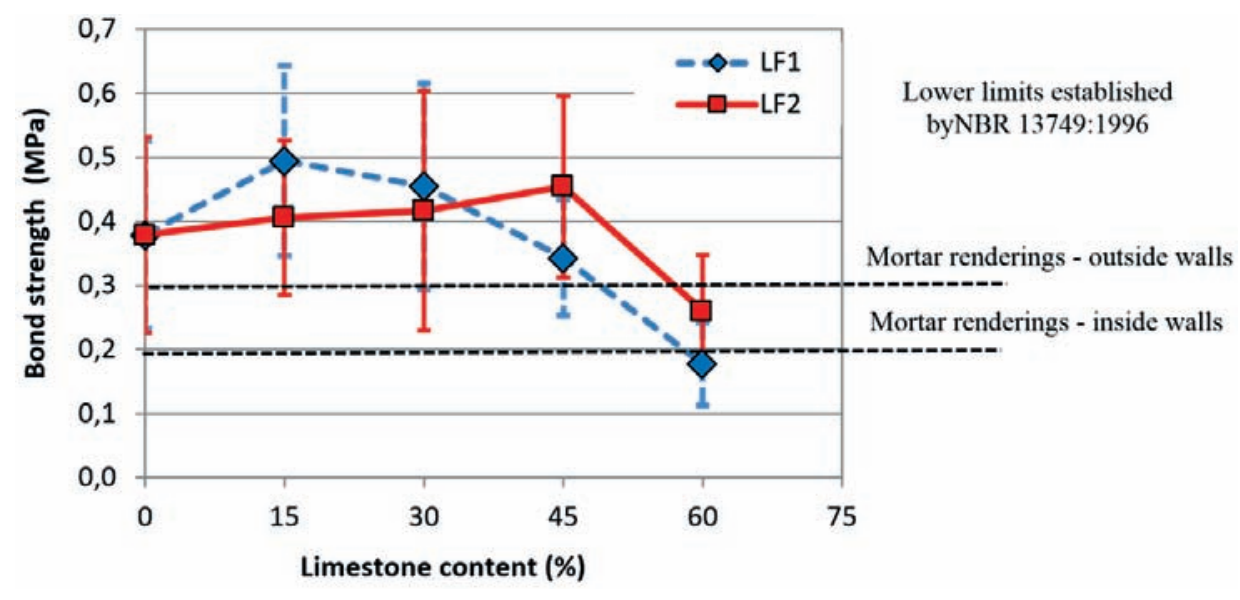

Fineness and particle size distribution of particles seem to be important. In all the cases, the replacement of binder by limestone fine LF1 resulted in tensile strength in average about $20 \%$ higher than the use of limestone fine LF2. For example, mortars with $15 \%$ of replacement of binder had a reduction in tensile strength of $13 \%$ and $20 \%$ for LF1 and LF2, respectively.

Particle size distribution of cement and fines can affect the packing of particles explaining this behaviour. The reduction of particle size tends to improve the packing decreasing the porosity of mortar and, thereby increasing the mechanical strength. This will occur if the particles are dispersed. Further investigations regarding the packing and dispersing particles will be developed in the future.

\subsection{Bond strength}

Table 6 shows the results of the variance analysis (ANOVA) ${ }^{2}$ of the effect of the type and content of limestone fine on bond strength. The results showed no significant differences between the types of limestone fines used. However, the limestone fine content significantly alters the bond strength value. There is no interaction between the type and the content of limestone used.

It is clear in Figure 6 that the replacement of the binder up to $45 \%$ by both limestone fines did not cause a decrease in the bond strength. For limestone content until $45 \%$ all the results have bond strength higher than those established by the NBR 13749: 1996 [25]. Only the mortar with limestone fine 1 in $60 \%$ level, did not reach the bond strength of lower limit for inside walls established by NBR 13749: 1996.

The performance reduction observed at higher levels of replacement may be occur owing to a large amount of agglomerating of the particles finer than cement. The agglomeration of the particles increases the effective size reducing packing and increasing the defects on mortar-substrate interface [21]. Antunes (2005) comparing the bond strength of mortars with and without dispersant admixture $(0.6 \%$ by weight of cement) found that the use of dispersing admixture increased in an average $29 \%$ of bond strength than without dispersant mortars [22]. As previously mentioned, the effect of dispersing mortar will be studied in future investigation. Due the high variability typical of this type of testing an independent repetition was made for mortars with $0 \% ; 45 \%$ and $60 \%$ of

Figure 7 - Independent repetition of bond strength test made for mortars with $0 \% ; 45 \%$ and $60 \%$ of replacement of binder by limestone fine 2 (LF2) using the same materials, mixing procedures, application and cure procedures and equipment, but different operators to check the experimental error. The results showed the same trend and the difference between the average of repetitions was less than $25 \%$

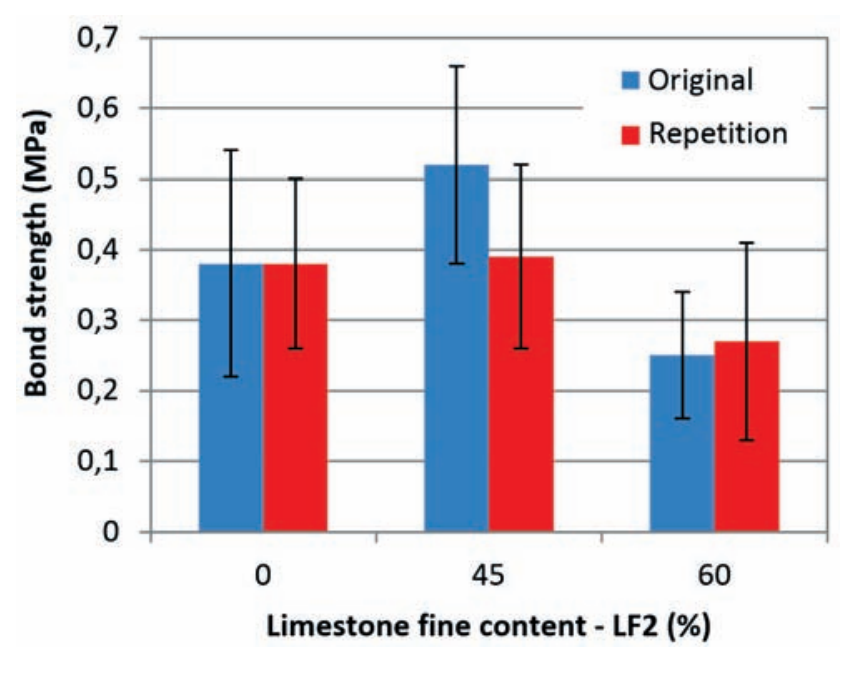




\section{Figure 8 - The relation between bond strength and tensile strength of mortars}

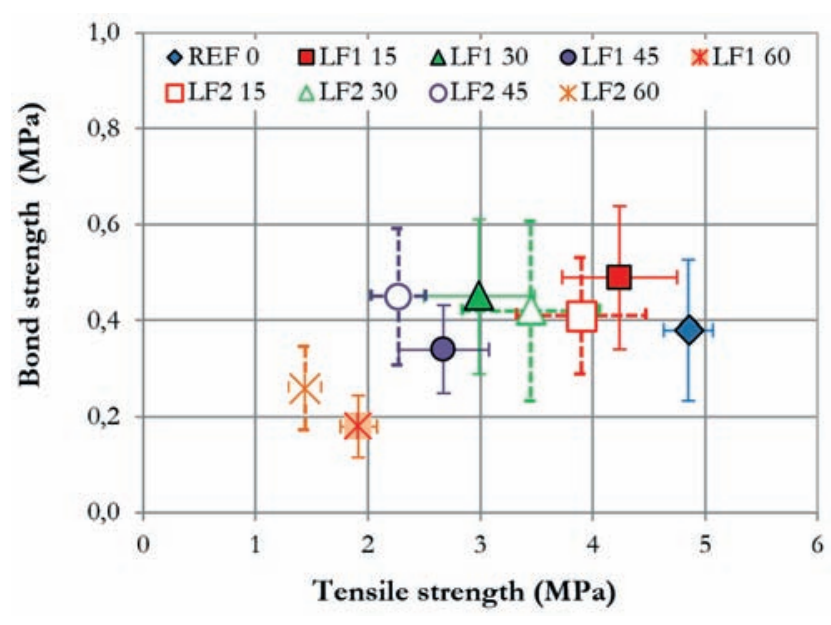

replacement of binder by limestone fine 2 (LF2) using the same materials, mixing procedures, application and cure procedures and equipment, but different operators to check the experimental error. The results showed the same trend and the difference between the average of repetitions was less than $25 \%$ (Figure 7 ).

All the mortars had rupture in mortar-substrate interface indicating that the interface region is the weakest part of the system. Thus, the bond strength express as the mechanical properties of transition zone. This indicates the enormous potential for improve the performance of this typical phase of cementitious materials.

The adhesive strength of the mortar-brick interface was 5-13 times lower than the tensile strength of the mortar body. This demonstrate that there is enormous potential for improving the performance of the ITZ. Although it is commom to find in the literature references direct correlation between the bond strength and mechanical properties of mortars. There was no correlation between the average bond strength and the corresponding average tensile strength (Fig. 8); this result is in accordance with that reported by Antunes [22]. The water/cement ratio determined the tensile strength $\left(R^{2}=95 \%\right.$, power function, statistically valid regression with homogeneous and random error); however, it had a smaller effect on the bond strength $\left(R^{2}=57 \%\right.$, linear, a regression model was not valid).

The bond strength is dependent on the Van der Waals forces [13] between the particles in the mortar layer and in the substrate; this is true irrespective of whether they are hydrated or not. As pointed out by Chaterjee, these forces occur whenever the particles come sufficiently close to each other such that there is no need for continuity of the atomic arrangement [12]. This seems to be valid, within limits, for mixtures of inert particles with hydrated phases and surfaces. The porosity of the interface is magnified by the wall effect which can be reduced by the presence of particles finer than the cement $[2,20]$.

\subsection{Binder use efficiency}

The effect of fines particles on the system performance can be measured by the binder intensity indicator (bi) defined as the amount of
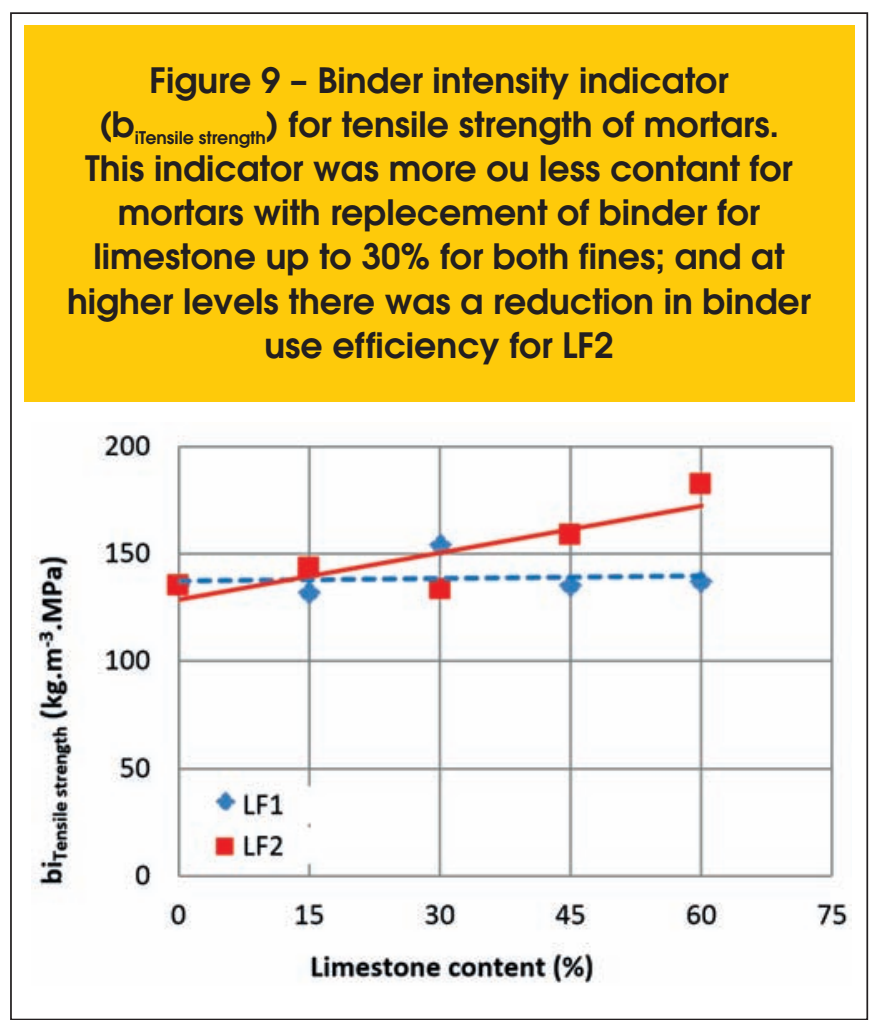

binder $\left(\mathrm{kg} / \mathrm{m}^{3}\right)$ used for $1 \mathrm{MPa}$ of tensile strength at 14 days. The higher this indicator the worse the performance of the formulation. For LF1, the indicator bi was kept constant while for the LF2 there was a general trend of the decreasing of binder use efficiency with the increase of levels of replacement of binder by this limestone fine (Figure 8). This may result from a change in packing of particles because this fine had a larger amount coarse particles than LF1. This hypothesis need to be confirmed by further investigations.

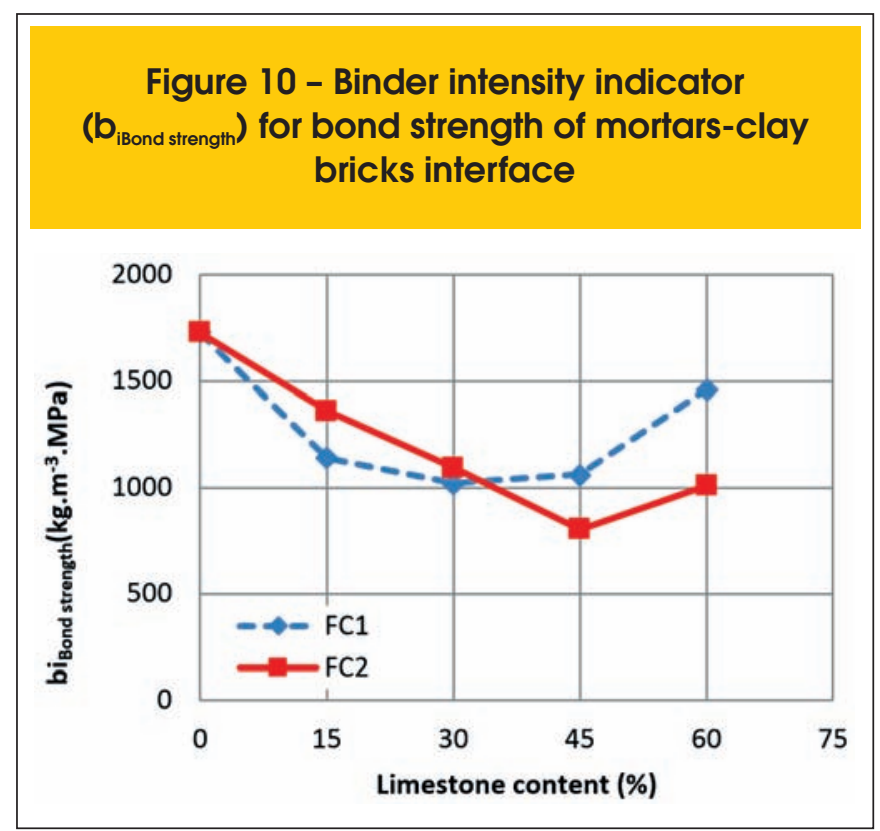


In terms of bond strength (Figure 9), the replacement of binder by limestone fines reduces the binder intensity indicator - that is, there is an increase of the binder use efficiency indicating that the amount of binder needed to produce $1 \mathrm{MPa}$ of bond strength is reduced when the fines particles are present. This occurs even if the bond strength of the limestone mortars is lower than the reference mortar. It was observed that even the replacement of binder by $45 \%$ of limestone fines there is no reduction of bond strength, remaining values within the acceptance limits of NBR 13749: 1996.

The results also suggested that the characteristics of the interface were less negatively affected by the dilution effect owing to the substitution of the cementitious materials by the limestone fines having similarly sized particles than did the properties of the mortar bulk. This conclusion is of great practical interest, it can be applied to improve the characteristics of the ITZ of concretes and useful for $\mathrm{CO}_{2}$ mitigation in the supply chain of the cement industry [24].

\section{Conclusions}

The effects of replacing the binder in mortars with limestone fines on the mechanical properties of the mortars, namely, the tensile and bond strengths of the mortar-brick interface, were studied. Two limestone fines, one with the average particle size as that of the binder and the other with much smaller average diameter particles, were used. The total water content were constant for all the investigated samples.

The replacement of the binder by the limestone fines at levels up to $15 \%$ reduces the tensile strength of mortars owing to dillution effect. By the other side, the replacement up to $45 \%$ did not affect the bond strength of the system mortar-substrate for both limestone studied. At higher levels $60 \%$ it was observed a reduction of this property.

There was no correlation between the average bond strength and the correspondent average tensile strength. In pratice it was possible to reduce the mortar tensile strength by a factor of 2.5 times without changing significantly the bond strength. The replacement of the binder by the limestone fillers also affected the characteristics of the ITZ in a very different manner that it did the mechanical properties, which are determined by the water/cement ratio. The binder content seemed to have less of an effect on the bond strength than it did on the tensile strength. It may be possible to formulate mortars with good adhesive strengths at lower binder contents by optimizing the particle size and their packing density using inert fines such as those of limestone fines. It was found that the bond strength of the mortars was 5-13 times lower than their tensile strength. These values indicate the extent to which the properties of mortars can be improved.

Finally, the replacement of the binder by limestone fines appears to reduce the binder intensity indicator related to bond strength up to $53 \%$. The same indicator related to tensile strength was almost constant. Therefore, the use of limestone fines seems to be a good method of increasing the binder use efficiency related to bond strength of mortars. This fact might be useful for $\mathrm{CO}_{2}$ mitigation in the supply chain of the cement industry.

The effect of the use of dispersing admixture and the evaluation of the properties of mortars in the fresh state associated with the replacement of binder by limestone fines are being investigated in parallel study.

\section{Acknowledgements}

The authors would like to acknowledge the support from the São Paulo Research Foundation - FAPESP (Research Grant no. 2010/10843-7), Coordination for the Improvement of Higher Education Personell - CAPES, and CONSITRA (Brazilian Consortium for Innovation on Rendering Mortars Technology) and R\&D ANEEL by Rheology Project 394-0929 / 2010 developed jointly by FUSP and Furnas.

\section{References}

[01] OLLIVIER, J. P.; MASO, J. C.; BOURDETTE, B. Interfacial transition zone in concrete. Advanced Cement Based Materials, v.2, 1985; p. 30-38.

[02] SCRIVENER, K. L.; CRUMBIE, A. K.; LAUGESEN, P. The Interfacial Transition Zone (ITZ) Between Cement Paste and Aggregate in Concrete. Interface Science, n. 12,2004; p. 411421.

[03] MOOSBERG-BUSTNES, H.; LAGERBLAD, B.; FORSSBERG, E. The function of fillers in concrete. Mat. Struct., n. 37, 2004; p. 74-81.

[04] LAWRENCE, P., CYR, M. \& RINGOT, E. Mineral admixtures in mortars: Effect of inert materials on short-term hydration. Cement and Concrete Research, n.33, 2003; p.1939-1947.

[05] MALHOTRA, V. M.; MEHTA, P. K. Pozzolanic and cementitious materials. Gordon and Breach: Amsterdam, The Netherlands, 1996.

[06] DAMINELI, B. L.; JOHN, V. M. Developing Low CO2 Concretes: Is Clinker Replacement Sufficient? The Need of Cement Use Efficiency Improvement. Key Engineering Materials, n.517, 2012; p. 342-351.

[07] MATSCHEI, T.; LOTHENBACH, B.; GLASSER, F. The role of calcium carbonate in cement hydration. Cement and Concrete Research, n. 37, 2007; p. 551-558.

[08] LOTHENBACH, B.; LESAOUT, G.; GALLUCCI, E.; SCRIVENER, K. Influence of limestone on the hydration of Portland cements. Cement and Concrete Research n. 38, 2008; p. 848-860.

[09] DAMIDOTA, D.; LOTHENBACH, B.; HERFORT, D.; GLASSER, F. P. Thermodynamics and cement science. Cement and Concrete Research, n. 41, 2011; p.679-695.

[10] BENTZ, D. P.; IRASSAR, E. F.; BUCHER, B. ; WEISS, W. $J$. Limestone fillers to conserve cement in low $\mathrm{w} / \mathrm{c}$ concretes: an analysis based on Powers' model. Concrete International 31, 2009.

[11] NEHDI, M. Optimization of high strength limestone filler cement mortars. Cement and Concrete Research, n. 26, 1996; p.883-893.

[12] TSIVILIS, S.; BATIS, G.; CHANIOTAKIS, E.; GRIGORIADIS, G.; THEODOSSIS, D. Properties and behavior of limestone cement concrete and mortar. Cement and Concrete Research, n.30, 2000; p.1679-1683.

[13] CAMILETTI, J.; SOLIMAN, A. M.; NEHDI, M. L. Effects of nano- and micro-limestone addition on early-age properties of ultra-high-performance concrete. Mater Struct 1-18 , 2012; doi:10.1617/s11527-012-9940-0

[14] HUNGER, M.; BROUWERS, H. J. H. Flow analysis of 
water-powder mixtures: Application to specific surface area and shape factor. Cement and Concrete Composites, n. 31, 2009; p.39-59.

[15] REDA TAHA, M. M.; EL-DIEB, A. S.; SHRIVE, N. G. Sorptivity: a reliable measurement for surface absorption of masonry brick units. Mater. Struct. n.34, 2005, p. 438-445.

[16] BENTZ, D. Replacement of 'coarse' cement particles by inert fillers in low w/c ratio concretesll. Experimental validation. Cement and Concrete Research, n. 35, 2005; p. 185-188.

[17] LAWRENCE, P.; CYR, M.; RINGOT, E. Mineral admixtures in mortars: Effect of inert materials on short-term hydration. Cement and Concrete Research, n. 33, 2003; p. 1939-1947.

[18] KENDALL, K. Molecular adhesion and its applications : the sticky universe. Kluwer Academic/Plenum: New York; London, 2001.

[19] CHATTERJEE, S. Load-bearing structures and crystal intergrowth. Nature, n.252, 1974; p.383.

[20] HU, J.; STROEVEN, P. Properties of the Interfacial Transition Zone in Model Concrete. Interface Science, n.12, 2004; p.389-397.

[21] ROY, D. M.; GRUTZECK, M. W.; SHI, D.; LUI, G. Cement paste aggregate interface microstructure. National Academy of Sciences, n. 79, 1993.

[22] ANTUNES, R. P. Influência da reologia e da energia de impacto na resistência de aderência de revestimentos de argamassa. Doctoral Thesis, Escola Politécnica, University of São Paulo, São Paulo, (2005).

[23] DAMINELI, B. L.; KEMEID, F. M.; AGUIAR, P. S.; JOHN V. M. Measuring the eco-efficiency of cement use. Cement and Concrete Composites n.32, 2010; p.555-562.

[24] DAMINELI, B. L.; PILEGGI, R. G.; JOHN, V. M. Lower binder intensity eco-efficient concretes. Eco-efficient concrete, v.1, n.624,2013.

[25] ASSOCIAÇÃO BRASILEIRA DE NORMAS TÉCNICAS. NBR 13479. Revestimento de paredes e tetos de argamassas inorgânicas - Especificação, 1996. 